використання електронної пошти (забезпечує оперативну доставку необхідних навчальних і методичних матеріалів, а також інформації організаційного характеру для учнів-слухачів МАН; доставку виконаних домашніх завдань викладачу; зворотній зв'язок між викладачем і учнем; спілкування учнів секцій між собою); усне спілкування між педагогом-тьютором і слухачем у режимі on-Line через Skype в голосовому та відеорежимах з одночасним підключенням великої кількості учасників; спілкування (усне, письмове, в режимі on-Line ) на форумах, у соціальних мережах «Однокласники», «Фейсбук», «У контакті», а також за допомого телефону та телефаксу.

Третій етап - підсумково-заліковий. Форма навчання - очна. Основні завдання етапу: систематизація знань і вмінь учнів - слухачів МАН; оцінювання індивідуальної успішності та виявлення ступеня задоволення учнів результатами своєї дослідницької роботи. Основний зміст етапу передбачає проведення конкурсу-захисту науководослідницьких робіт учнів - членів МАН, підсумкових занять, заліків, конференцій, тестування, а також діагностування юних науковців за підсумками роботи.

Підсумовуючи викладене вище, можна стверджувати, що дистанційне навчання як нова форма організації освітнього процесу суттєво впливає на формування нового змісту позашкільної освіти, модифікацію й удосконалення організаційних форм i методів навчання інтелектуально обдарованої учнівської молоді в освітній системі Малої академії наук України.

Проведене нами дослідження не вичерпує всіх аспектів окресленої проблеми. Подальшого вивчення потребують питання аналізу засобів реалізації дистанційного навчання в освітній системі МАН, зокрема таких, як навчально-методичні та програмно-технічні.

\title{
Література
}

1. Організація очно-дистанційного навчання у Львівській обласній Малій академії наук : [навч.-метод. посіб. / [І. А. Бородчук, Н. Н. Знетиняк, І. А. Лема та ін. ; упоряд. О. В. Лісовий, С. О. Лихота]. - К. : ТОВ «Інформаційні системи», 2010.- 82 с. 2. Тихенко Л. В. Розвиток творчих здібностей учнівської молоді в освітньо-виховній системі «Мала академія наук України»: [навч.-метод. посіб.]/ Л. В. Тихенко, C. І. Ніколаєнко. - Суми : ВТД «Університетська книга», 2007. - 120 с. 3. Харченко Н. I. Методика застосування засобів дистанційного навчання та формування знань в інноваційному освітньому середовищі/ Інноваційні технології навчання обдарованої молоді: [матеріали Міжнародної науково-практичної конференції], (м. Київ, 6-7 грудня 2012 року). - К. : Інститут обдарованої дитини, 2012. - C. $310-314$.

\section{МОДЕЛЬ ЗАБЕЗПЕЧЕННЯ ІНФОРМАЦЙНОЇ БЕЗПЕКИ МОЛОДШИХ ШКОЛЯРІВ}

Шишкіна К. М. Модель забезпечення інформаційної безпеки молодших школярів.

У статті проаналізовано проблеми забезпечення інформаційної безпеки школярів у загальноосвітньому навчальному закладі й розроблено систему заходів, необхідних для iii забезпечення. Розглянуто структурну і функціональну моделі забезпечення інформаційної безпеки молодшого школяра в он-лайн середовищі. 
Ключові слова: забезпечення інформаційної безпеки, он-лайн безпека, модель, загрози, способи захисту, організаційний захист, виховні заходи.

Шишкина К. М. Модель обеспечения информационной безопасности младших школьников.

В статье проанализированы проблемы обеспечения информационной безопасности школьников в общеобразовательном учебном заведении; разработана система мер, необходимых для ее обеспечения. Рассмотрены структурная и функциональная модели обеспечения информационной безопасности младшего школьника в онлайн среде.

Ключевые слова: обеспечения информационной безопасности, онлайн безопасность, модель, угрозы, способы защиты, организационная защита, воспитательные меры.

Shyshkina K. M. The model of ensuring information security of children in primary school.

The article deals with the problem of information security of children in secondary schools and the system of measures that are necessary to ensure it. The structural and functional models of information security of children at school online are reviewed.

Key words: information security, online safety, model, threats, methods of security, organizational defense, educational measures.

Трансформація системи цінностей школярів $\epsilon$ результатом загальної комп’ютеризації та інформатизації, упровадження інформаційних та комунікативних технологій в освітній процес школи, розширення інформаційного освітнього простору.

Нині визначено низку впливових процесів розвитку глобальної інформаційної мережі Інтернет та пов'язаних 3 нею сервісів на особистість школяра: електронна пошта, засоби інтерактивного спілкування, соціальні мережі, мережеві комп'ютерні ігри тощо. Інтернет, як глобальне інформаційне середовище, існує близько двох десятиліть, але тільки зараз розпочав формування як відкрите інформаційне середовище $з$ усіма позитивними та негативними аспектами впливу на спосіб життя людини і людську психіку.

Мета статті полягає у з'ясуванні особливостей забезпечення інформаційної безпеки молодшого школяра та розробленні функціональної моделі з забезпечення ІБ.

Питання моделювання в педагогічних дослідженнях висвітлюються в наукових доробках В. Афанасьєва, В. Беспалько, Б. Глинського, В. Давидова, Я. Неуйміна, I. Новак, Е. Семенюка, Н. Сичкової, М. Шишкіна, В. Штофф та ін.

Під моделлю в статті розумітимемо штучно створене для вивчення явище (предмет, процес, ситуація), аналогічне іншому явищу (предмету, процесу, ситуації [1]. При визначенні моделі в педагогічному дослідженні акцентують на таких ознаках:

- відображення і (або) відтворення (імітація) досліджуваного об'єкта, процесу в моделі;

- здатність до заміщення об'єкта процесу;

- здатність надавання нової інформації;

- наявність точних умов і правил побудови моделі та переходу від інформації моделі до інформації про об’єкт (Е. Семенюк, В. Давидов, В. Штофф та ін.).

Науковець В. Краєвський визначає модель як систему елементів, відтворюючи деякі сторони, зв'язки, функції об'єкта дослідження. В основі моделювання - певна 
відповідність (але не тотожність) між досліджуваним об'єктом (оригіналом) і його моделлю, головною ознакою теоретичної моделі є чітко фіксований зв'язок елементів, припускає певну структуру, відображатиме внутрішні, істотні відносини [4].

Отже, за допомогою моделі можна отримати нову інформацію про об'єкти, виявити і вивчити ті взаємозв'язки, які недоступні для пізнання іншими способами. Крім цього, модель дає узагальнену характеристику об'єктам, є еталоном цільової реалізації.

Н. Кузьміна підкреслює, що моделі в педагогіці виконують такі гносеологічні функції [5]: ілюстративну, трансляційну, пояснювальну, передбачувальну. За їх допомогою можна ілюструвати ту чи ту галузь знань, умінь, здібностей педагога, учня, визначити, якими мають бути з позиції результату.

Моделювання системи полягає в побудові певного образу, адекватної досліджуваної системи, і отримання за допомогою побудованої моделі необхідних характеристик реальної системи. Отже, весь процес моделювання можна розподілити на два складники: побудова моделі та реалізація моделі задля отримання необхідних характеристик системи.

Дотепер розроблено й апробовано досить багато методів моделювання, що дозволяють ефективно розв'язувати задачі аналізу й синтезу великих систем різної природи й архітектури, а також управління процесами їх функціонування. Однак проблема побудови моделі забезпечення інформаційної безпеки школярів не знайшла належного розкриття у працях відомих педагогів-дослідників.

Цілі забезпечення інформаційної безпеки школярів загалом можуть бути сформульовані як побудова оптимальних систем захисту інформації від негативного впливу інформації та формування інформаційної культури учнів. Ю. Богатирьова окреслює такі цілі моделювання системи інформаційної безпеки в освітній організації:

- захист учнів, вихованців, педагогів, їх прав та інтересів, майна від небезпечних впливів;

- забезпечення ефективного функціонування та розвитку освітньої організації;

- зниження збитку від негативних впливів загроз інформаційній безпеки та наслідків від ризиків;

- поліпшення якості життя, підвищення добробуту учнів і педагогів (за рахунок зниження психологічних розладів, смертності, підвищення збереження здоров'я, зниження ризику розкрадання інформації) [1].

Задля реалізації поставлених цілей зазвичай використовують спрощену модель захисту, але в реальних ситуаціях, особливо тоді, коли висуваються підвищені вимоги до забезпечення інформаційної безпеки, застосовується багаторівневий захист (модель подано на рис. 1) Для того, щоб дістатися до закритої інформації, порушник повинен у цьому випадку подолати («зламати») кілька рівнів захисту [1]. 


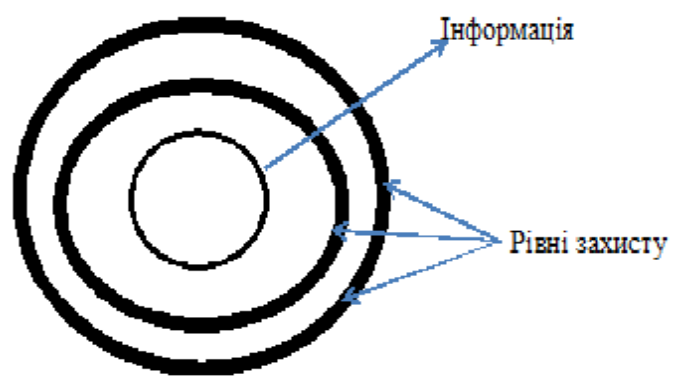

Рис. 1 Модель багаторівневого захисту інформації

Пропонована модель безпеки особистості (див. рис. 2), яка створює загальне уявлення про різноманіття дій та заходів забезпечення інформаційної безпеки школяра.

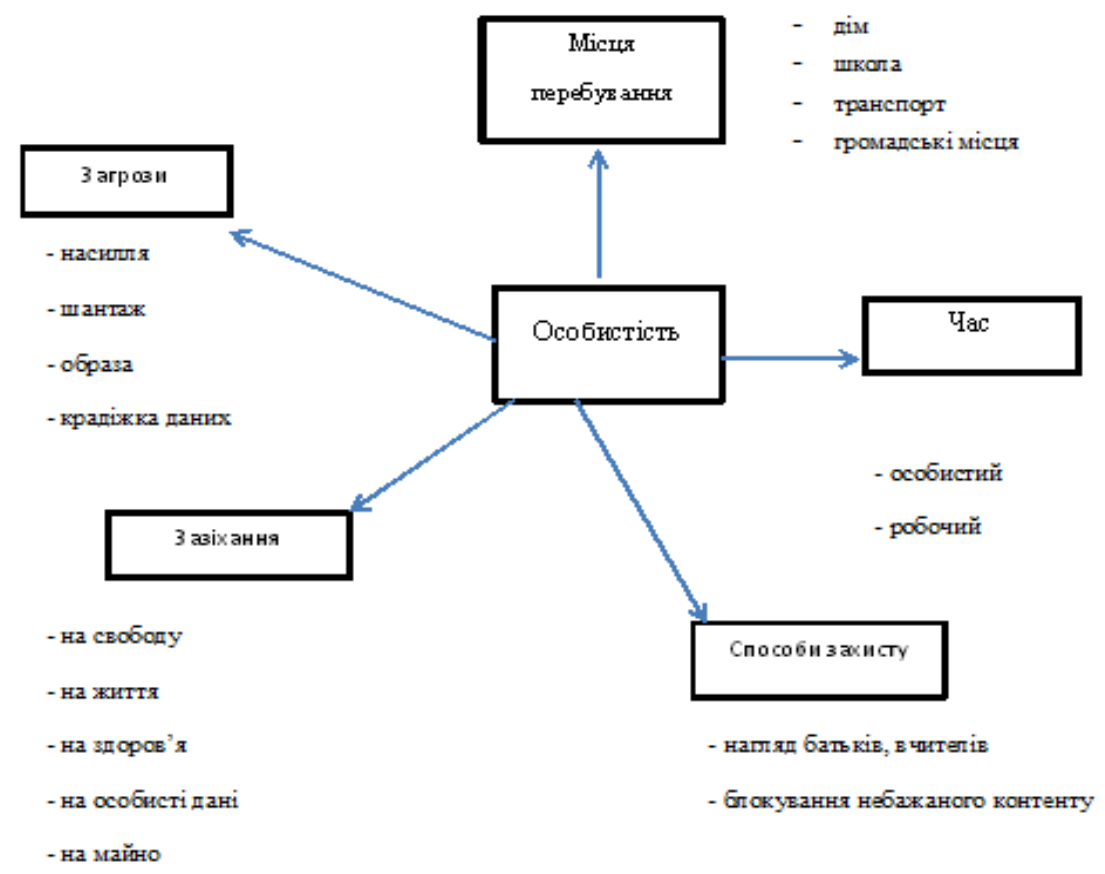

Рис. 2 Модель безпеки особистості

Об’єктом інформаційної безпеки окресленої моделі $є$ особисте інформаційне середовище школяра. Одним зі шляхів розв'язання проблем інформаційної безпеки сучасних школярів - в організації безпечного особистого інформаційного простору у 
школі і сім’ї. В умовах шкільної освіти забезпечення інформаційної безпеки учнів пропонується розглядати як сукупність діяльності щодо недопущення шкоди здоров’ю, свідомості, психіці дитини. Відтак, керуюча та координаційна функції забезпечення та навчання інформаційної безпеки у школі повинна бути покладена на вчителя інформатики [6].

Однією з головних умов успішного навчання інформаційної безпеки є позиція вчителя, сутність якої становить безумовне прийняття дитини, бажання зміцнити іiі позицію в соціумі, надати своєчасну підтримку в саморозвитку, захистити від вчинення неприйнятних дій, відкрити шлях до соціалізації та адаптації особистості.

У моделі забезпечення інформаційної безпеки школярів (див. рис. 3) також представлені загрози інформаційної безпеки (як сукупність чинників та умов, що виникають у процесі взаємодії об'єкта безпеки з іншими об'єктами (суб'єктами). Загальна структура загрози складається з об'єкта загрози, ії джерела та виявлення загрози [2].

Інформаційні небезпеки сучасних молодших школярів - це негативний аспект переходу до інформаційного суспільства в умовах глобалізації інформаційного простору й тотальної доступності інформації, що формуються під впливом вище вказаних інформаційних загроз і ризиків, яким сучасний школяр повинен уміти протидіяти, організовуючи свою навчальну діяльність.

Інформаційні небезпеки сучасних молодших школярів - це негативний аспект переходу до інформаційного суспільства в умовах глобалізації інформаційного простору й тотальної доступності інформації, що формуються під впливом вище вказаних інформаційних загроз і ризиків, яким сучасний школяр повинен уміти протидіяти, організовуючи свою навчальну діяльність.

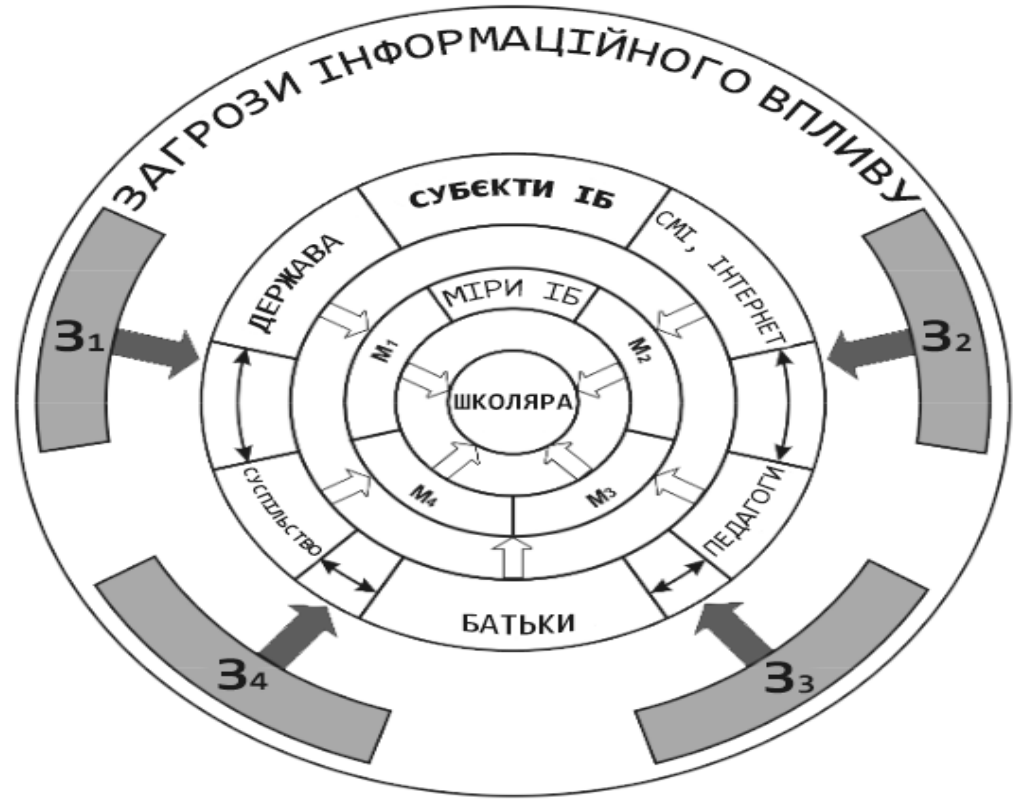




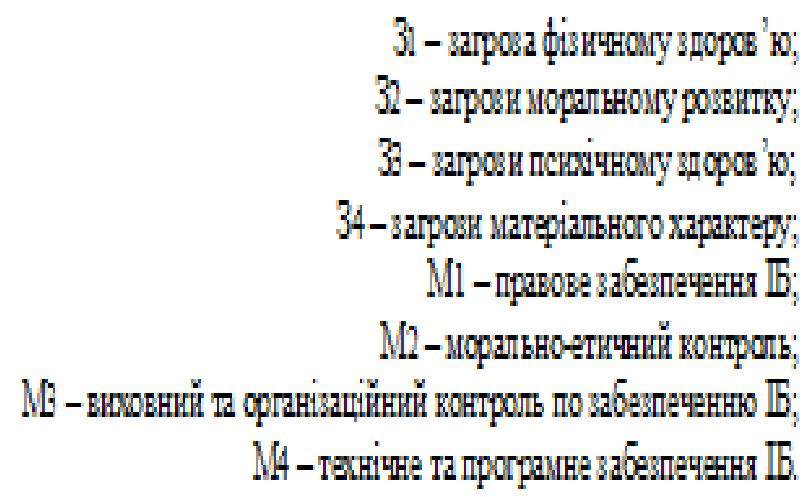

Рис. 3 Модель забезпечення інформаційної безпеки молодших школярів

У зв'язку з тим, що інформатизація суспільства призводить до виникнення нових чинників ризику, в теорії та методиці професійної освіти і викладання інформатики ставиться завдання формування у школярів уміння відстоювати свої права в питаннях інформаційної безпеки особистості. Відповідно, в педагогіці досліджуються педагогічні умови забезпечення інформаційної безпеки учнів. Для школярів, їх батьків, учителів розробляються конкретні рекомендації, покликані попередити або звести до мінімуму негативні наслідки використання комп'ютерної техніки в педагогічному процесі та повсякденному житті. Не менш важливим питанням побудови моделі забезпечення ІБ молодших школярів $\epsilon$ визначення суб'єктів інформаційної безпеки (див. рис. 3), тобто тих, хто впливає на інформаційну безпеку і несе відповідальність за іiі забезпечення. Визначають такі рівні суб'єктів ІБ, а саме: держава, суспільство, особистість [4].

На рівні держави здійснюється нормативно-правове регулювання питань інформаційної безпеки неповнолітніх, організовується оновлення змісту навчальних програм, підручників із питань безпеки в курсі інформатики. Всі ці заходи по забезпеченню ІБ називатимемо правовими.

На рівні суспільства діють такі суб'єкти: громадські та комерційні організації, релігійні організації, засоби масової інформації (телебачення, радіо, друковані видання, Інтернет), загальноосвітні навчальні заклади, батьки, вчителі.

Дитина аналізує й оцінює отриману інформацію відповідно до сформованих батьками, вчителями, суспільством і державою здібностей до оцінювання загроз в інформаційному просторі, вмінь інформаційного самозахисту, а також особливостей особистого інформаційного середовища. На наш погляд, це так званий фільтр, що повинен сформувати у школяра суб'єкти інформаційної безпеки.

Недостовірна, неетична, деструктивна інформація виходить від основних джерел інформації, а так само від засобів інформаційного впливу, чиннить певний вплив на одержувача інформації- школяра. Це вплив може нанести шкоду здоров'ю (перевтома, психологічна залежність, соматичні захворювання, зниження працездатності тощо.), етичні проблеми (переоцінка моральних норм, зниження інтересу до читання, перенесення зразків поведінки 3 віртуальної дійсності в реальність тощо), труднощі в навчанні (відсутність часу на навчання, перевантаження зайвою інформацією, зниження успішності) [3]. 
3 урахуванням зарубіжного та вітчизняного досвіду інформаційної безпеки суб'єкти інформаційної безпеки зобов'язані здійснювати заходи щодо забезпечення безпеки особистої інформаційного середовища молодшого школяра в межах таких напрямків:

Правове забезпечення інформаційної безпеки - це спеціальні закони, нормативні акти, правила, процедури та заходи, які забезпечують захист особистого інформаційного середовища учня на законодавчій та правовій основах для реалізації єдиної державної політики у сфері захисту дітей від інформації, що завдає шкоди їх здоров'ю та розвитку [2].

Моральний і етичний контроль, має на меті дотримання школярами під час здійснення інформаційної діяльності норм і правил поведінки в суспільстві, а також мережевої культури та етики, які складаються відповідно до міри поширення інформаційних технологій у сучасному інформаційному суспільстві.

Захист психіки і здоров'я дитини - це заходи спрямовані на актуалізацію потреби молодших школярів в здоров’і, фізичному благополуччі, а також як засоби досягнення життєво важливих цінностей, профілактиці комп'ютерної та Інтернет залежності серед учнів, педагогічна та психологічна допомога в питаннях зменшення інформаційних небезпек у життєдіяльності школярів.

Організаційний захист - це регламентація інформаційної діяльності школярів, контроль використання мережевих сервісів і співтовариств, які мають на меті завдання шкоди особистості школяра [2].

Виховні заходи із забезпечення ІБ- формування культури безпеки, відповідальності за дії в інформаційному просторі, виховання і зміцнення духовноморальних цінностей, патріотизму, готовності батьків і педагогів до прийняття позиції дитини та поваги їі самостійності.

Технічне та програмне забезпечення ІБ - це використання різних апаратних $\mathrm{i}$ програмних засобів, що перешкоджають нанесенню матеріального або морального збитку особистої інформації [2].

Вищезазначені заходи щодо забезпечення інформаційної безпеки мають бути зумовлені, насамперед, віковими, психологічними і фізіологічними особливостями школярів як особистості, що формується, і тим, що порівняно $з$ представниками інших соціальних груп, значною мірою схильна до негативного впливу інформації, яка завдає шкоди моральному розвитку і здоров'ю [ЗОшибка! Источник ссылки не найден.].

Відтак на основі моделі забезпечення ІБ молодших школярів, принципів захисту інформації та напрямів іiі реалізації в освітній діяльності повинна бути побудована концепція забезпечення інформаційної безпеки учнів. При цьому під концепцією розумітимемо офіційно прийняту систему поглядів на проблему інформаційної безпеки на рівні держави, суспільства або окремої особистості. Для того, щоб організувати ефективний захист від шкідливого інформаційного оточення, необхідно розробити концепцію забезпечення інформаційної безпеки особистості, що охоплюватиме: систему сучасних поглядів, ідей, цільових установок і пріоритетних напрямків, загальні положення, принципи, зміст, технологію, методологічні та теоретичні положення професійної діяльності суб'єктів процесу забезпечення інформаційної безпеки особистості школярів.

Концепція інформаційної безпеки загалом повинна містити перелік заходів та засобів, які за мінімальних витрат на їх реалізацію забезпечать максимальну безпеку. Концепція безпеки буде методологічною основою реалізації так званої політики 
безпеки. Відповідна політика безпеки в загальноосвітньому закладі, у вигляді відповідного документа, встановлюватиме правила контролю шкідливого контенту, окреслюватиме шляхи їх реалізації, визначатиме напрямки діяльності щодо забезпечення ІБ всіх суб'єктів освітнього процесу.

Подальших досліджень потребують організаційно-педагогічні проблеми застосування контент-фільтрації під час доступу до ресурсів і сервісів мережі Інтернет у вітчизняних загальноосвітніх навчальних закладах.

\section{Література}

1. Богатырева Ю. И. Информационная безопасность школьников в образовательной среде : теория и практика высшей школы / Ю. И. Богатырева. - Тула, 2013. - 160 c. 2. Доктрина забезпечення інформаційної безпеки України [Електронний pecypc]. Режим доступу: http://zakon4.rada.gov.ua/laws/show/514/2009 3. Ковальчук В. Н Методика забезпечення он-лайн безпеки старшокласників у навчально-виховному процесі школи [Електронний ресурс] / В. Н. Ковальчук. Режим доступу: http://www.journal.iitta. gov.ua 4. Краевский В. В. Качество педагогики и методологическая культура педагога / В. В. Краевский. - М. : 1991 212 с. 5. Кузьмина Н. В. Методы системного педагогического исследования / Н. В. Кузьмина. - Л., 1980. - 141 с. 6. Шишкіна М. П Модельний підхід у побудові комп'ютерно-орієнтованого середовища / М. П. Шишкіна. - Суми, 2004. - С. 17-21.

Віктор Шутько

\section{СУЧАСНИЙ ПОГЛЯД НА ПРОБЛЕМИ ФІЗИЧНОГО ВИХОВАННЯ І ФОРМУВАННЯ ОСОБИСТОСТІ ШКОЛЯРА}

Шутько В. В. Сучасний погляд на проблеми фізичного виховання і формування особистості школяра.

Статтю присвячено проблемі оптимального поєднання фізичного виховання 3 іншими видами виховання: розумовим, моральним, естетичним, трудовим, які направленні на формування особистості школяра, для розв'язанння низки важливих проблем, які склалися у фізичному вихованні загальноосвітніх закладів.

Ключові слова: фізичне виховання, формування особистості, гармонійний розвиток, педагогічний процес.

Шутько В. В. Современный взгляд на проблемы физического воспитания и формирования личности школьника.

Статья посвящена проблеме оптимального сочетания физического воспитания с другими видами воспитания: умственным, нравственным, эстетическим, трудовым, которые направлены на формирование личности школьника, для решения ряда важных проблем, которые сложились в физическом воспитании общеобразовательных учреждений

Ключевые слова: физическое воспитание, формирование личности, гармоничное развитие, педагогический процесс.

Shutko V. V. Modern look at the problems of physical education and formation of the individuality of a student.

The article is dedicated to combining physical education with other types of education: intellectual, moral, aesthetic, labor, to the direction of the formation of the individual 